\section{Expression of chemokines and gelatinase $B$ in sympathetic ophthalmia}

\author{
Abstract \\ Purpose To examine the expression of \\ gelatinase B (matrix metalloproteinase-9) \\ and the chemokines monocyte chemotactic \\ protein-1 (CCL2/MCP-1) and stromal \\ cell-derived factor-1 (CXCL12/SDF-1) in \\ sympathetic ophthalmia (SO). \\ Methods Five enucleated exciting eyes \\ with a clinical diagnosis and typical \\ histopathological findings of SO were \\ studied by immunohistochemical techniques \\ using a panel of monoclonal antibodies \\ directed against gelatinase B, MCP-1, and \\ SDF-1. In addition, a panel of monoclonal \\ and polyclonal antibodies was used to \\ characterize the composition of the \\ inflammatory infiltrate. \\ Results In all cases, the extensive uveal \\ inflammatory infiltrate was organized as a \\ diffuse infiltrate and as large granulomas \\ consisting of epithelioid cells and \\ multinucleated giant cells. $\mathrm{CD20}{ }^{+} \mathrm{B}$ \\ lymphocytes predominated in the diffuse \\ infiltrate and $\mathrm{CD}^{+} \mathrm{T}$ lymphocytes were few. \\ The monocyte/macrophage marker CD68 was \\ expressed in scattered inflammatory \\ mononuclear cells and within granulomas and \\ Dalen-Fuchs nodules. Most of the \\ inflammatory cells were HLA-DR ${ }^{+}$. \\ Immunoreactivity for gelatinase B, MCP-1, \\ and SDF-1 was observed in cells within \\ granulomas and in scattered epithelioid cells. \\ Immunoreactivity for MCP-1 was noted in \\ retinal pigment epithelial cells. Endothelial \\ cells of choriocapillaries showed weak \\ immunoreactivity for SDF-1. \\ Conclusions Gelatinase B, MCP-1, and \\ SDF-1 might have a pathogenic role in \\ the recruitment of leucocytes into the eye \\ in SO. \\ Eye (2007) 21, 649-657. doi:10.1038/sj.eye.6702342; \\ published online 7 April 2006
}

AM Abu El-Asrar ${ }^{1}$, S Struyf ${ }^{2}$, C Van den Broeck ${ }^{3}$ J Van Damme², G Opdenakker², K Geboes ${ }^{4}$ and P Kestelyn ${ }^{5}$

Keywords: sympathetic ophthalmia; uveitis; gelatinase B; monocyte chemotactic protein-1; stromal cell-derived factor-1

\section{Introduction}

Sympathetic ophthalmia (SO) is defined as a bilateral granulomatous panuveitis following penetrating ocular trauma and intraocular surgery to one eye. ${ }^{1}$ The injured eye is referred to as the exciting eye and the fellow eye as the sympathizing eye. Although the

pathophysiology of the disease is not clearly understood, an autoimmune process incited by the initial penetrating injury or by surgery appears to play a significant role. The typical histopathology is characterized by a diffuse non-necrotizing granulomatous infiltration seen throughout the uveal tract. The inflammatory cell infiltrate is composed primarily of numerous lymphocytes with nests of non-necrotizing granulomas that consist mainly of epithelioid and multinucleated giant cells. At the level of the retinal pigment epithelium, multiple DalenFuchs nodules are observed that are composed of inflammatory cells, mainly monocytes, macrophages, and epithelioid cells. ${ }^{2-4}$

The mechanisms governing the recruitment of leucocytes into the eye in SO are not fully understood. Chemokines and matrix metalloproteinases (MMPs), in particular gelatinase B (MMP-9), play key roles in the migration of leucocytes to sites of inflammation. ${ }^{5,6}$ Chemokines are a superfamily of 5- to $8-\mathrm{kDa}$ secreted proteins that direct the recruitment of leucocytes to sites of inflammation. These chemokines are grouped into the $\mathrm{CXC}, \mathrm{CC}, \mathrm{C}$, and $\mathrm{CX} 3 \mathrm{C}$ subfamilies on the basis of the arrangement of the conserved cysteine residues. ${ }^{5}$ Monocyte chemotactic
${ }^{1}$ Department of Ophthalmology, College of Medicine, King Saud University, Riyadh, Saudi Arabia

${ }^{2}$ Rega Institute for Medical Research, Laboratory of Molecular Immunology, University of Leuven, Leuven, Belgium

${ }^{3}$ Department of Pathology, University of Ghent, Ghent, Belgium

${ }^{4}$ Laboratory of Histochemistry and Cytochemistry, University of Leuven, Leuven, Belgium

${ }^{5}$ Department of Ophthalmology, University of Ghent, Ghent, Belgium

Correspondence: AM Abu El-Asrar, Department of Ophthalmology, King Abdulaziz University Hospital, Airport Road, PO Box 245 Riyadh 11411, Saudi Arabia Tel: + 9661477 5723; Fax: +96614775724. E-mail: abuasrar@ KSU.edu.sa

Received: 11 October 2005 Accepted in revised form: 14 February 2006 Published online: 7 April 2006 
protein-1 (CCL2/MCP-1), the most potent CC chemokine, is a chemoattractant and activator for monocytes, T lymphocytes, basophils, and natural killer cells. ${ }^{7}$ Stromal cell-derived factor-1 (CXCL12/SDF-1), constitutively expressed in a broad range of tissues, was initially cloned from mouse bone marrow stromal cells and as CXC chemokine originally described as pre-B-cell growthstimulating factor. ${ }^{8}$ It is a chemoattractant for monocytes, naive and memory $\mathrm{T}$ lymphocytes, and $\mathrm{B}$ lymphocytes. ${ }^{9-11}$ SDF-1 is also a costimulatory factor for $\mathrm{CD}^{+}$ T-lymphocyte activation. ${ }^{12}$ In view of the presence of an important mononuclear cell infiltrate in SO, MCP-1 and SDF-1 are candidate chemokines for investigation. In addition, pharmacological SDF-1 blockage was effective in animal models of autoimmune diseases. AMD3100, a potent and specific antagonist of the SDF-1 chemokine receptor CXCR4, inhibited autoimmune joint inflammation in interferon-gamma receptor-deficient mice. ${ }^{13}$

The MMPs represent a family of $\mathrm{Zn}^{2+}$-containing endopeptidases that are recognized as key enzymes both for normal extracellular matrix turnover and for the exaggerated extracellular matrix breakdown associated with pathologic conditions including tumour cell invasion and metastasis, angiogenesis, inflammatory reactions, wound healing, and scar formation..$^{14,15}$ Gelatinase B cleaves denatured collagens (gelatins), collagen types IV, V, VII, and X, elastin, and fibronectin. ${ }^{14}$ Because of its unique and broad substrate spectrum, its involvement in leucocyte migration, and its role in other chronic inflammatory and autoimmune diseases, ${ }^{6,15}$ we hypothesized that excessive production of gelatinase B may play a role in the pathogenesis of SO.

In the present study, we investigated the subtypes of mononuclear cells present in the inflammatory infiltrate and the expression of gelatinase $B$ and the chemokines MCP-1 and SDF-1 in five enucleated exciting eyes with the classic clinical presentation and typical histopathological findings of SO.

\section{Materials and methods}

Five formalin-fixed, paraffin-embedded enucleated eyes with the classic clinical presentation and typical histopathologic findings of SO were obtained from the registry of Ophthalmic Pathology, Department of Ophthalmology, University of Ghent, Belgium. All the ocular tissues were of the exciting eyes. Serial sections of $5 \mu \mathrm{m}$ thickness were utilized for the study and stained with haematoxylin and eosin for routine analysis and studied by immunohistochemical techniques.

\section{Immunohistochemical staining}

After deparaffinization, endogenous peroxidase was abolished with $2 \%$ hydrogen peroxide in methanol for
$20 \mathrm{~min}$, and nonspecific background staining was blocked by incubating the sections for $5 \mathrm{~min}$ in normal swine serum. For CD3, immunoglobulin (Ig) A, IgG, and $\mathrm{MCP}-1$ detection, antigen retrieval was performed by boiling the sections in $10 \mathrm{mM}$ Tris-EDTA buffer $(\mathrm{pH}$ 9) for $30 \mathrm{~min}$. For HLA-DR, CD20, SDF-1, and gelatinase B detection, antigen retrieval was performed by boiling the sections in $10 \mathrm{~mm}$ citrate buffer ( $\mathrm{pH}$ 6) for $30 \mathrm{~min}$. For CD68 detection, the sections underwent trypsinization for $10 \mathrm{~min}$ at $37^{\circ} \mathrm{C}$ using a mixture of $0.1 \%$ trypsin (Sigma-Aldrich, Bornem, Belgium) and $0.1 \% \mathrm{CaCl}_{2}$ at $\mathrm{pH}$ 7.8. Subsequently, the sections were incubated with the monoclonal and polyclonal antibodies listed in Table 1. Optimal working concentration and incubation time for the antibodies were determined earlier in pilot experiments. For gelatinase B immunohistochemistry, slides were incubated for $30 \mathrm{~min}$ with gelatinase B-specific REGA-2D9 monoclonal antibody (1:100). The mouse monoclonal antibody REGA-2D9 was raised against natural human neutrophil gelatinase $B$. This implies that the antigen preparation was devoid of gelatinase A. The REGA-2D9 is an $\mathrm{IgG}_{1}$ subtype with a dissociation constant $\left(K_{\mathrm{d}}\right)$ value of $9.5 \times 10^{-10} \mathrm{M}$, which implies high specificity. ${ }^{16}$ For CD3, CD68, HLA-DR, CD20, IgA, IgG, MCP-1, and SDF-1 immunohistochemistry, the sections were incubated for $30 \mathrm{~min}$ with goat anti-rabbit or anti-mouse immunoglobulins conjugated to peroxidase-labelled dextran polymer (EnVision ${ }^{+}$; Dako, Carpinteria, CA, USA). For gelatinase B immunohistochemistry, the sections were incubated for $30 \mathrm{~min}$ with the biotinylated secondary antibody and reacted with the avidinbiotinylated peroxidase complex (Dako). The reaction product was visualized by incubation for $10 \mathrm{~min}$ in $0.05 \mathrm{M}$ acetate buffer at $\mathrm{pH} 4.9$, containing $0.05 \%$

Table 1 Monoclonal and polyclonal antibodies used in the study

\begin{tabular}{llcl}
\hline Primary antibody & Dilution & $\begin{array}{c}\text { Incubation } \\
\text { time (min) }\end{array}$ & Source $^{\mathrm{a}}$ \\
\hline Anti-CD3 (pc) & $1 / 50$ & 30 & Dako \\
Anti-CD20 (clone L26) (mc) & $1 / 100$ & 30 & Dako \\
Anti-CD68 (clone KP1) (mc) & $1 / 100$ & 30 & Dako \\
Anti-HLA-DR & $1 / 50$ & 30 & Dako \\
$\quad$ (clone TAL-1B5) (mc) & $1 / 100$ & 30 & Dako \\
Anti-IgA (pc) & $1 / 50$ & 30 & Dako \\
Anti-IgG (pc) & $1 / 25$ & 120 & $\begin{array}{l}\text { R\&D } \\
\text { Anti-MCP-1/CCL2 }\end{array} \quad$ Systems \\
$\quad$ (clone 23002) (mc) & $1 / 50$ & 30 & $\begin{array}{l}\text { R\&D } \\
\text { Anti-SDF-1/CXCL12 } \\
\text { (clone 79018) (mc) }\end{array}$ \\
\hline
\end{tabular}

a Location of manufacturers: Dako, Glostrup, Denmark; R\&D Systems Europe Ltd, Abingdon, UK.

Ig, immunoglobulin; MCP-1, monocyte chemotactic protein-1; SDF-1, stromal cell-derived factor-1; pc, polyclonal; mc, monoclonal. 
3-amino-9-ethylcarbazole (Sigma-Aldrich) and 0.01\% hydrogen peroxide, resulting in bright-red immunoreactive sites. The slides were faintly counterstained with Harris haematoxylin. Finally, the sections were rinsed with distilled water and coverslipped with glycerol. Omission or substitution of the primary antibody with an irrelevant antibody of the same species and staining with chromogen alone were used as negative controls. Control antibodies included anti-carcinoembryonic antigen (Dako), which is an $\mathrm{IgG}_{1}$ Kappa, and anti-cytokeratin 10/13 (Dako), which is an $\mathrm{IgG}_{2 \mathrm{a}}$ Kappa. Sections from patients with Crohn's disease were used as positive controls.

\section{Results}

Table 2 provides the data on each of the five cases concerning the age of the patient at the time of injury, sex, inciting event, time interval from injury to onset of symptoms in the sympathizing eye, and time interval from onset of inflammation in the sympathizing eye to enucleation of the exciting eye. None of the patients was on systemic immunosuppressive therapy before enucleation of the exciting eye.

In all cases, an important inflammatory infiltrate composed of mononuclear cells was present. The cellular infiltrate showed a diffuse distribution involving the whole thickness of the uveal tract but was more intense on the scleral side of the choroid. It was composed primarily of numerous lymphocytes with few plasma cells and in addition many large, epithelioid cells containing dark brown pigment granules. Among the lymphocytic infiltrate, there were many large granulomas consisting of epithelioid cells with or without multinucleated giant cells (Figure 1).

Dalen-Fuchs nodules were observed in three cases.

Immunohistochemical studies revealed no staining in the negative control slides and when the chromogen alone was applied. A summary of the results is given in Table 3. In all cases, the lymphocytic infiltrate of the uveal tract was predominantly composed of CD20 ${ }^{+} \mathrm{B}$ lymphocytes, whereas $\mathrm{CD}^{+} \mathrm{T}$ lymphocytes were fewer (Figure 2). The majority of plasma cells were $\operatorname{IgA}^{+}$. $\mathrm{CD} 68^{+}$monocytes/macrophages were scattered in the diffuse inflammatory infiltrate. Epithelioid cells and multinucleated giant cells within granulomas and cells in Dalen-Fuchs nodules were CD68 ${ }^{+}$(Figure 3). Most of the inflammatory mononuclear cells were HLA-DR ${ }^{+}$. In addition, epithelioid cells and multinucleated giant cells within granulomas were HLA-DR ${ }^{+}$.

In all cases, cytoplasmic immunoreactivity for MCP-1, SDF-1, and gelatinase B was noted predominantly in
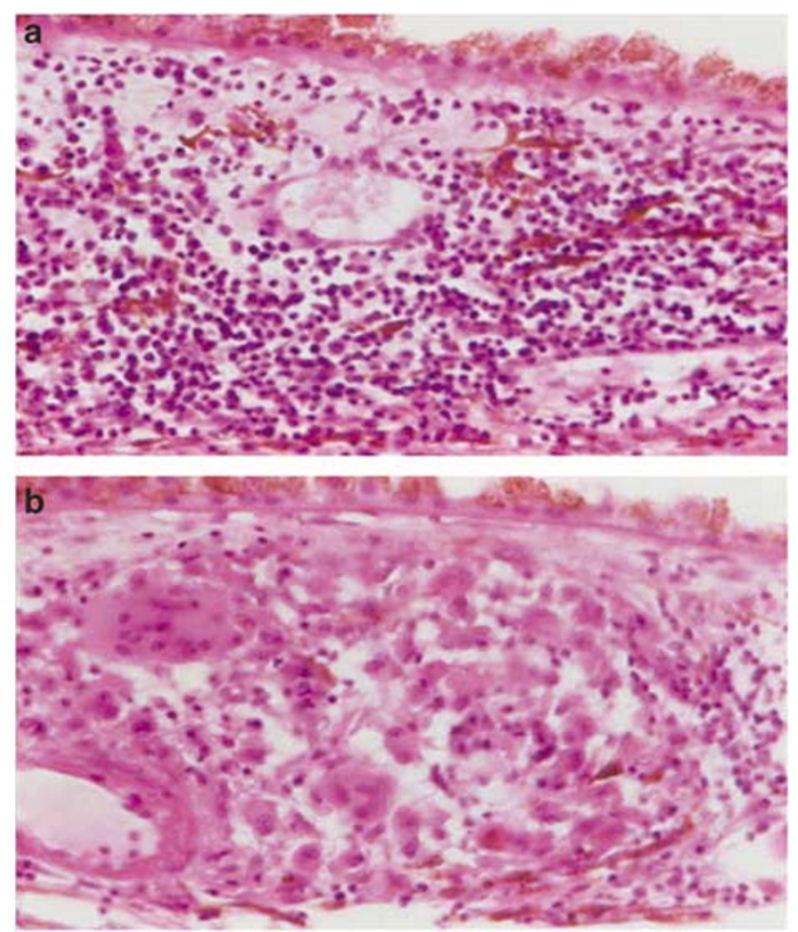

Figure 1 Photomicrographs showing extensive inflammatory infiltration in the choroid composed predominantly of lymphocytes (a), and a choroidal granuloma composed predominantly of epithelioid cells and multinucleated giant cells (b) (haematoxylin and eosin, original magnification, $\times 40$ ).

Table 2 Subject characteristics

\begin{tabular}{|c|c|c|c|c|}
\hline $\begin{array}{l}\text { Case } \\
\text { number }\end{array}$ & $\begin{array}{c}\text { Age } \\
\text { (years)/sex }\end{array}$ & Inciting event & $\begin{array}{l}\text { Time interval from injury } \\
\text { to onset of symptoms in the } \\
\text { sympathizing eye (months) }\end{array}$ & $\begin{array}{l}\text { Time interval from onset of } \\
\text { symptoms in the sympathizing } \\
\text { eye and enucleation of the } \\
\text { exciting eye (days) }\end{array}$ \\
\hline 1 & $49 \mathrm{M}$ & Complicated cataract surgery with iris incarceration & 1 & 10 \\
\hline 2 & $43 \mathrm{~F}$ & Complicated pars plana vitrectomy & $7 \frac{1}{2}$ & 15 \\
\hline 3 & $71 \mathrm{~F}$ & Complicated cataract surgery & $1 \frac{1}{2}$ & 3 \\
\hline 4 & $35 \mathrm{M}$ & $\begin{array}{l}\text { Unsuccessful pars plana vitrectomy for } \\
\text { penetrating injury }\end{array}$ & 8 & 7 \\
\hline 5 & $51 \mathrm{M}$ & Complicated cataract surgery with iris incarceration & 2 & 13 \\
\hline
\end{tabular}


Table 3 Summary of immunohistochemical data

\begin{tabular}{|c|c|c|c|c|c|}
\hline Case number & $\begin{array}{c}\text { CD3 }^{+} T \\
\text { lymphocytes }(\%)\end{array}$ & $\begin{array}{c}C D 20^{+} B \\
\text { lymphocytes }(\%)\end{array}$ & $\begin{array}{c}\text { CD68 }{ }^{+} \text {monocytes/ } \\
\text { macrophages }(\%)\end{array}$ & $\begin{array}{l}\text { Ig } A^{+} \text {plasma } \\
\text { cells }(\%)\end{array}$ & $H L A D R^{+}(\%)$ \\
\hline 1 & $20-25$ & $60-65$ & 15 & 5 & $80-90$ \\
\hline 2 & $30-35$ & $45-50$ & 10-15 & 5 & $60-70$ \\
\hline 3 & $25-30$ & $55-60$ & 10-15 & 5 & $80-90$ \\
\hline 4 & $20-25$ & 50-55 & 15 & 5 & $70-80$ \\
\hline 5 & $20-25$ & $60-65$ & 15 & 5 & $80-90$ \\
\hline
\end{tabular}
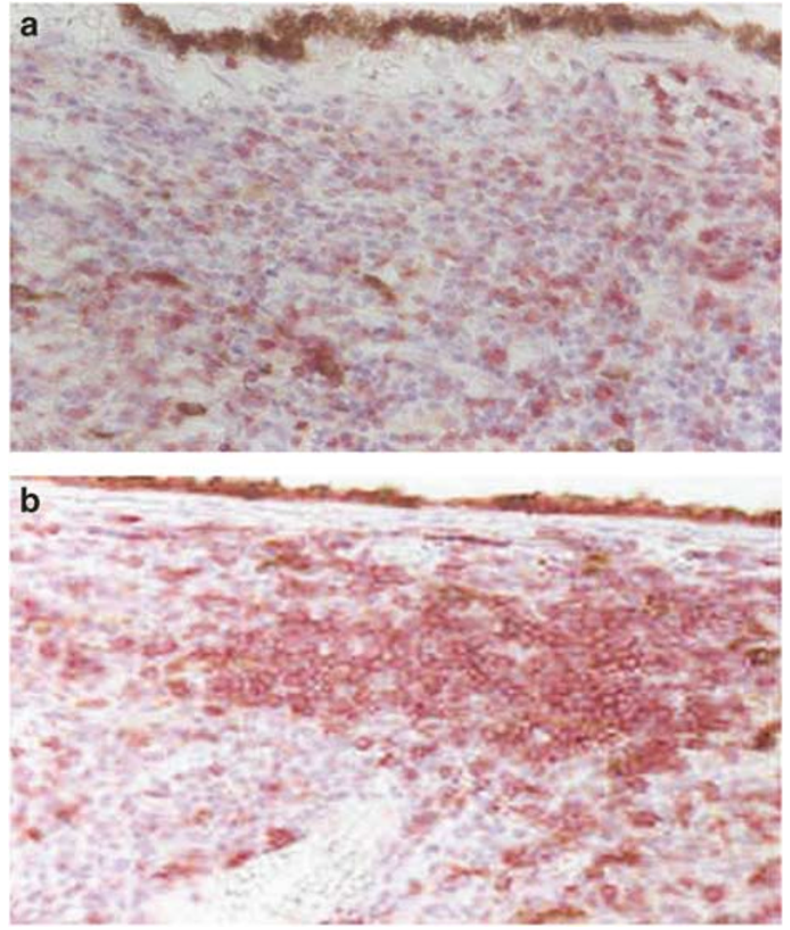

Figure 2 Immunohistochemical staining for T-cell marker (CD3) (a) and B-cell marker (CD20) (b) showing predominance of $\mathrm{CD}^{+}{ }^{+} \mathrm{B}$ cells in the choroidal inflammatory infiltrate (original magnification, $\times 40$ ).

epithelioid cells and multinucleated giant cells within granulomas but also in the scattered epithelioid cells present in the diffuse inflammatory infiltrate.

Cytoplasmic immunoreactivity for MCP-1 was also noted in retinal pigment epithelial cells (Figure 4), whereas a weak SDF-1 immunoreactivity was noted on endothelial cells of the choriocapillaries.

\section{Discussion}

In the present study, we demonstrated the following points: (1) B cells predominated in the uveal infiltrates in all SO cases; (2) cells from the monocyte/macrophage lineage, particularly the epithelioid cells and multinucleated giant cells within the choroidal
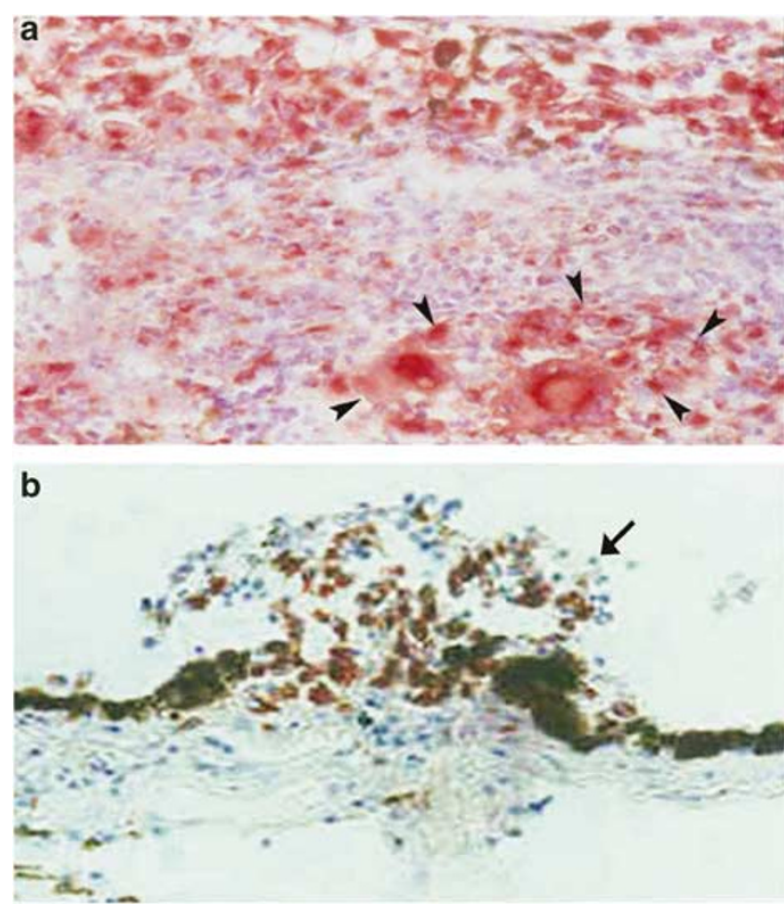

Figure 3 Immunohistochemical staining for monocyte/macrophage marker (CD68) showing immunoreactivity within choroidal granuloma (arrowheads) and in scattered inflammatory mononuclear cells (a), and in inflammatory mononuclear cells within Dalen-Fuchs nodule (arrow) (b) (original magnification, $\times 40)$.

granulomas, were the major cell types expressing gelatinase $\mathrm{B}$ and the chemokines MCP-1 and SDF-1; and (3) retinal pigment epithelial cells expressed MCP-1.

Immunohistochemical studies have described the choroidal infiltrates of SO to be predominated by activated $\mathrm{T}$ cells, and the proportion of $\mathrm{B}$ cells varies from 10 to $40 \% .^{2}$ Chan $e t l^{2}$ have reported a predominance of $\mathrm{T}$ helper cells in the early stage of disease and $\mathrm{T}$ suppressor cells at a later stage of the disease, indicating that the cellular kinetics in SO changes over time. Our results, however, show predominance of $B$ cells in the uveal inflammatory infiltrate. Our findings are in agreement with previous reports that demonstrated predominance of $\mathrm{B}$ cells in the choroidal inflammatory 

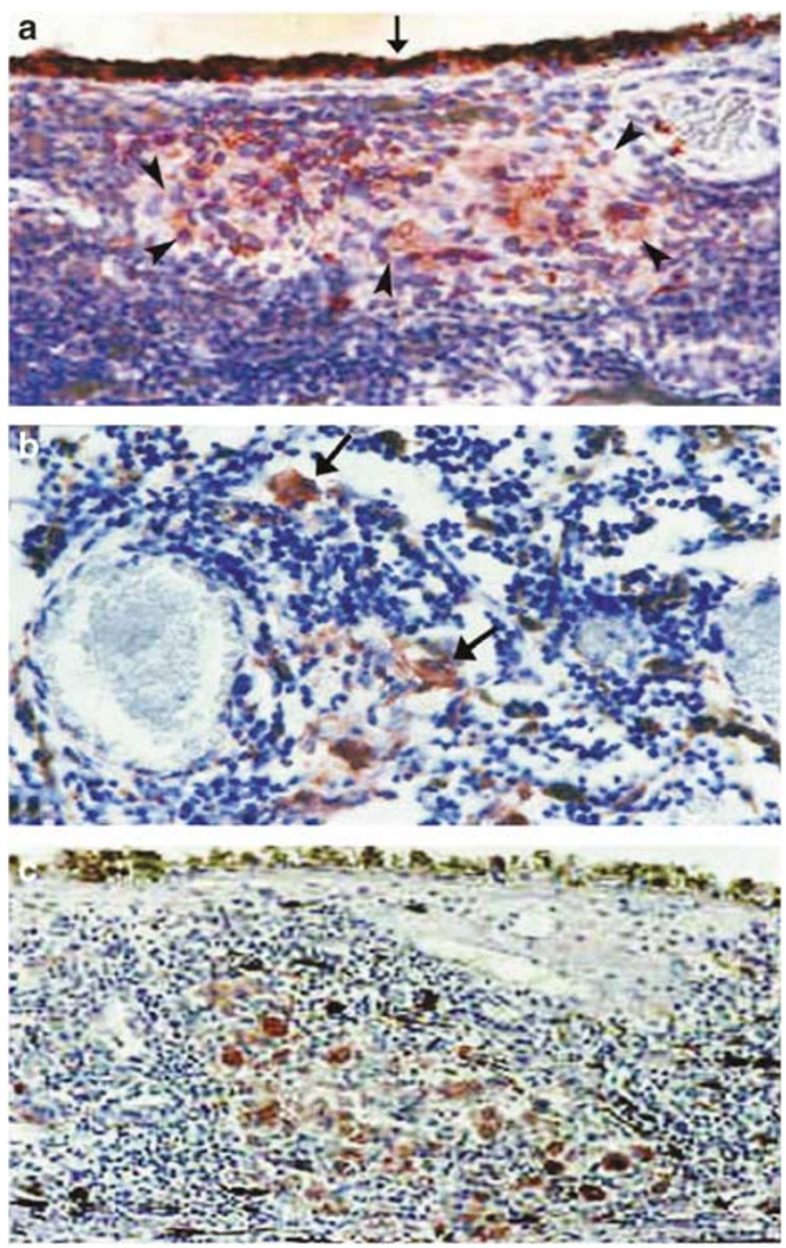

Figure 4 Immunohistochemical staining for $\mathrm{MCP}-1$ showing immunoreactivity within choroidal granuloma (arrowheads) and in retinal pigment epithelial cells (arrow) (a), SDF-1 showing immunoreactivity in scattered inflammatory mononuclear cells (arrows) (b), and gelatinase B showing immunoreactivity in cells within choroidal granuloma (c) (original magnification, $\times 40$ ).

infiltrate in $\mathrm{SO}^{4,17}$ In an immunohistochemical study of 29 exciting eyes, Shah $e t a l^{4}$ demonstrated that predominance of $B$ cells in four cases of their series was significantly correlated with longer duration of the disease. They suggested that, although SO is a T-cellmediated disease, the predominance of $\mathrm{B}$ cells in some cases may represent the end stage of the disease process, or seems a secondary pathological process. In their study, the duration of disease referred to inflammation in the sympathizing eye was less than 3 months in 16 cases, 3-9 months in three cases, and more than 9 months in 10 cases. In the present study, it was not possible to determine from the medical records the duration of inflammation in the exciting eyes before the onset of symptoms in the sympathizing eyes. However, the time interval from onset of symptoms in the sympathizing eyes and enucleation of the exciting eyes was 15 days or less. In addition, the predominance of B cells in the choroidal inflammatory infiltrate was reported in one case of progressive subretinal fibrosis, a variant of $\mathrm{SO}_{1}^{18}$ and in one case of multifocal choroiditis. ${ }^{19}$ Interestingly in experimental autoimmune uveitis, B-cell numbers increased progressively to become the predominant cell type in end-state lesions. ${ }^{20}$

Functional antigen-driven B-cell follicle-like structures with germinal centres and numerous plasma cells are found in the target tissues of autoimmune diseases such as the salivary glands of Sjögren's syndrome, rheumatoid synovial membranes, and thyroid glands from patients with Hashimoto's thyroiditis and Grave's disease. ${ }^{21,22} \mathrm{~B}$ cells have many potential key roles in the pathogenesis of autoimmune diseases. It has recently been proposed that B lymphocytes may play a more critical role in the induction of immunological activities as an antigenpresenting cell population, and that they are essential for the initial development and/or activation of autoreactive $\mathrm{T}$ cells in rheumatoid arthritis. ${ }^{23}$ In addition, they can secrete chemokines and proinflammatory cytokines, produce autoantibodies, and activate T cells. ${ }^{24}$ The notion that $\mathrm{B}$ cells might be critical to the development of rheumatoid arthritis led to the extension of the use of selective B-cell depletion with anti-CD20 therapy to this condition and a recent double blind controlled trial has shown encouraging results. ${ }^{24}$ In the present study, the majority of plasma cells were IgA ${ }^{+}$, suggesting a pathogenic role for IgA in SO. The formation of IgAcontaining immune complexes can activate the alternative complement pathway. Furthermore, there is increasing evidence that many leucocytes have receptors for IgA and binding of $\operatorname{IgA}$ to these receptors triggers a variety of effector functions. ${ }^{25}$ Similarly, the isotype of rheumatoid factor produced by B-cell lines developed from B-cell populations infiltrating the synovial tissue of patients with advanced rheumatoid arthritis was mostly IgA. ${ }^{26}$ In addition, several studies showed raised serum levels of $\operatorname{IgA}, \operatorname{Ig} A$ rheumatoid factor, and IgA-containing circulating immune complexes in rheumatoid arthritis and that IgA rheumatoid factors are produced locally in salivary glands and in synovial tissue. ${ }^{27,28}$ Furthermore, rheumatoid arthritis patients with a predominantly increased IgA rheumatoid factor had a more erosive disease and a high frequency of associated sicca syndrome..$^{29}$ The prevalence of IgA rheumatoid factor in juvenile rheumatoid arthritis was also found to be significantly higher in the polyarticular subset than the pauciarticular and the systemic onset group. ${ }^{30}$

SDF-1 is a chemokine that plays an important role in B-cell development, trafficking, and activation. ${ }^{8-11}$ Several studies suggested that SDF-1 may have a crucial role in the development of autoimmune disease. Matin 
et $a l^{31}$ demonstrated that the chemokine SDF-1 may be an essential chemoattractant in trafficking and migration of mature autoreactive B cells from bone marrow to the periphery or inflammatory sites in the development of autoimmune diabetes. Furthermore, they showed that anti-SDF-1 antibody was effective in inhibiting autoimmune diabetes in non-obese diabetic mice. ${ }^{31}$ Additionally, the administration of anti-SDF-1 antibody prevented the development of autoantibodies, nephritis, and death in a murine model of lupus. ${ }^{32}$ The expression of SDF-1, which is capable of inducing lymphocyte migration to lymphoid organs, ${ }^{33}$ is increased in chronically inflamed tissues such as rheumatoid arthritis synovium, ${ }^{34-36}$ and the thyroid gland from patients with autoimmune thyroid disease..$^{22}$ On the basis of a wide expression of SDF-1 in rheumatoid arthritis synovium, several studies demonstrated that SDF-1 and its receptor CXCR4 are involved in $\mathrm{CD}^{+}$and $\mathrm{CD} 8^{+}{ }^{+} \mathrm{T}-\mathrm{cell}{ }^{34,35}$ and $\mathrm{CD} 8^{+}$monocyte/macrophage ${ }^{36}$ migration to and retention in rheumatoid arthritis synovium. The expression of SDF-1 by monocytes/macrophages and endothelial cells in $\mathrm{SO}$ agrees with immunolocalization studies in rheumatoid arthritis synovium, ${ }^{36}$ and suggests a pathogenic role of SDF-1 in the recruitment of leucocytes including B lymphocytes into the eye. Our results are in agreement with a recent report that demonstrated early upregulation of SDF-1 mRNA during the evolution of experimental autoimmune anterior uveitis. ${ }^{37}$

Granulomatous inflammation is a specific type of chronic inflammation that is characterized by monocyte recruitment and activation and the accumulation of macrophages and their derived cells, epithelioid cells, and multinucleated giant cells. ${ }^{38}$ Kreipe $e t ~ a l^{39}$ demonstrated that multinucleated giant cells are highly stimulated cells of the monocyte/macrophage lineage at a terminal stage of maturation. MCP-1 is an important mediator of monocyte-rich pathological processes. In vitro studies have shown that MCP-1 is a potent monocytic chemotactic factor that can also upregulate adhesion molecule expression and cytokine production by monocytes. ${ }^{7,40}$ In the present study, MCP-1 immunoreactivity was predominantly associated with epithelioid cells and multinucleated giant cells present in granulomas. Our observations are consistent with previous reports showing that MCP-1 is produced in granulomatous inflammation and that MCP-1 reactivity is present primarily in macrophages, epithelioid cells, and multinucleated giant cells within granulomas. ${ }^{41-44}$ He $e t a l^{42}$ demonstrated that phagocytosis can serve as an important stimulus for MCP-1 production by macrophages. In addition, Flory et $a l^{41}$ demonstrated that administration of anti-MCP-1 antibody resulted in a dramatic decrease in the number and size of granulomas in a rat model of glucan-induced pulmonary granulomatous vasculitis.

In the present study, immunoreactivity for MCP-1 was also detected in retinal pigment epithelial cells. Our results are in agreement with previous in vitro studies that demonstrated active MCP- 1 secretion by human retinal pigment epithelial cells stimulated with the inflammatory cytokines interleukin- $1 \beta$ or tumour necrosis factor- $\alpha{ }^{45-47}$ Furthermore, it was shown that MCP-1 secreted by retinal pigment epithelial cells was bioactive and that antibodies directed against MCP-1 strongly inhibited monocyte chemotaxis elicited by supernatants of retinal pigment epithelial cells. ${ }^{45}$ In general, the expression of MCP-1 in $\mathrm{SO}$ is consistent with previous reports, which demonstrated upregulation of MCP-1 protein and mRNA in the eyes of animals with experimental autoimmune uveitis ${ }^{37,48-50}$ and in the aqueous humour from patients with acute anterior uveitis. $^{51}$

In previous studies, we and others have described increased levels of gelatinase B in aqueous humour samples from patients with active uveitis that correlated significantly with the clinical disease activity. ${ }^{52,53}$ Here we demonstrate that epithelioid cells and multinucleated giant cells in SO granulomas exhibited cytoplasmic immunoreactivity for gelatinase B. The intracellular localization of gelatinase B in cells from the monocyte/ macrophage lineage can be interpreted as evidence of active synthesis of this enzyme because macrophages do not store this metalloproteinase. ${ }^{54}$ Similarly, previous studies demonstrated immunoreactivity for gelatinase $B$ in epithelioid cells, multinucleated giant cells, and macrophages within granulomas in other human granulomatous disorders. ${ }^{55-57}$

Expression of gelatinase B has been associated with a wide variety of pathological processes, including autoimmune diseases such as multiple sclerosis, ${ }^{58}$ rheumatoid arthritis, ${ }^{59}$ and type I diabetes. ${ }^{60}$ The mechanism of action of gelatinase B in the pathogenesis of autoimmunity may be through the cleavage of substrate proteins into immunodominant epitopes. Further processing and presentation of the protein fragments on major histocompatibility complex class II molecules on the surface of antigen-presenting cells activates autoreactive T cells. ${ }^{58}$ In addition, gelatinase B is an important effector molecule for the migration of leucocytes. ${ }^{6}$ As one of the main components of endothelial basement membrane is type IV collagen, which is a substrate of gelatinase $\mathrm{B}_{1}^{61}$ gelatinase $\mathrm{B}$ might increase the extravasation of leucocytes into the eye through the basement membrane zone underlying endothelial cell layer. Gelatinase B could also render basement membranes vulnerable and increase vascular permeability leading to disruption of the blood-ocular 
barrier in patients with SO. Therefore, selective inhibition of gelatinase B should be considered as a potential therapy in patients with uveitis. Recently, El-Shabrawi et $a l^{62}$ demonstrated that selective inhibition of gelatinase A and gelatinase B completely prevented the development of uveitis in almost half of the animals with experimental autoimmune uveitis.

In conclusion, the findings reported in this study provide evidence that immunoreactivity for gelatinase $\mathrm{B}$ and the chemokines MCP-1 and SDF-1 was predominantly associated with epithelioid cells and multinucleated giant cells within the choroidal granulomas in SO. These findings suggest a pathogenic role for gelatinase B and the chemokines MCP-1 and SDF-1 in the regulation of leucocyte recruitment in SO.

\section{Acknowledgements}

We thank Mr Johan Van Even, Ms Christel Van den Broeck, and Ms Marie-Thérése Logier for technical assistance, and Ms Connie B Unisa-Marfil for secretarial work.

\section{References}

1 Fuchs E. Über sympathisierende Entzündung (nebst Bemerkungen über serose traumatische Iritis). Albrecht von Graefes Arch Ophthalmol 1905; 61: 365-456.

2 Chan C-C, Nussenblatt RB, Fujikawa LS, Palestine AG, Stevens Jr G, Parver LM et al. Sympathetic ophthalmia: immunopathological findings. Ophthalmology 1986; 93 : 690-695.

3 Chan C-C, Ben Ezra D, Hsu S-M, Palestine AG, Nussenblatt RB. Granulomas in sympathetic ophthalmia and sarcoidosis: immunohistochemical study. Arch Ophthalmol 1985; 103: 198-202.

4 Shah DN, Piacentini MA, Burnier Jr MN, McLean IW, Nussenblatt RB, Chan C-C. Inflammatory cellular kinetics in sympathetic ophthalmia: a study of 29 traumatized (exciting) eyes. Ocul Immunol Inflam 1993; 1: 255-262.

5 Struyf S, Proost P, Van Damme J. Regulation of the immune response by the interaction of chemokines and proteases. Adv Immunol 2003; 81: 1-44.

6 Opdenakker G, Van den Steen PE, Van Damme J. Gelatinase B: a tuner and amplifier of immune functions. Trends Immunol 2001; 22: 571-579.

7 Proost P, Wuyts A, Van Damme J. Human monocyte chemotactic proteins-2 and -3: structural and functional comparison with MCP-1. J Leukoc Biol 1996; 59: 67-74.

8 Nagasawa T, Hirota S, Tachibana K, Takakura N, Nishikawa $\mathrm{S}$, Kitamura $\mathrm{Y}$ et al. Defects of $\mathrm{B}$ cell lymphopoiesis and bone-marrow myelopoiesis in mice lacking the CXC chemokine PBSF/SDF-1. Nature 1996; 382: 635-638.

9 Bleul CC, Fuhlbrigge RC, Casasnovas JM, Aiuti A, Springer TA. A highly efficacious lymphocyte chemoattractant, stromal cell-derived factor 1 (SDF-1). J Exp Med 1996; 184: 1101-1109.

10 Bleul CC, Schultze JL, Springer TA. B lymphocyte chemotaxis regulated in association with microanatomic localization, differentiation state, and B cell receptor engagement. J Exp Med 1998; 187: 753-762.

11 Mcleod SJ, Li AHY, Lee RL, Burgess AE, Gold MR. The Rap GTPases regulate $B$ cell migration toward the chemokine stromal cell-derived factor-1 (CXCL12): potential role for Rap2 in promoting B cell migration. J Immunol 2002; 169: 1365-1371.

12 Mauki T, Lipsky PE. Cutting edge: stromal cell-derived factor- 1 is a costimulator for CD4 ${ }^{+} \mathrm{T}$ cell activation. J Immunol 2000; 164: 5010-5014.

13 Matthys P, Hatse S, Vermeire K, Wuyts A, Bridger G, Henson GW et al. AMD3100, a potent and specific antagonist of the stromal cell-derived factor- 1 chemokine receptor CXCR4, inhibits autoimmune joint inflammation in IFN-gamma receptor-deficient mice. J Immunol 2001; 167: 4686-4692.

14 Woessner JF. Matrix metalloproteinases and their inhibitors in connective tissue remodelling. FASEB J 1991; 5: 2145-2154.

15 Opdenakker G, Van Damme J. Cytokines and proteases in invasive processes: molecular similarities between inflammation and cancer. Cytokine 1992; 4: 251-258.

16 Paemen L, Martens E, Masure S, Opdenakker G. Monoclonal antibodies specific for natural human neutrophil gelatinase B used for affinity purification, quantitation by two-site ELISA and inhibition of enzymatic activity. Eur J Biochem 1995; 234: 759-765.

17 Auw-Haedrich C, Loeffler KU, Witschel H. Sympathetic ophthalmia: an immunohistochemical study of four cases. Ger J Ophthalmol 1996; 5: 98-103.

18 Lim W-K, Chee S-P, Sng I, Nussenblatt RB, Chan C-C. Immunopathology of progressive subretinal fibrosis: a variant of sympathetic ophthalmia. Am J Ophthalmol 2004 138: 475-477.

19 Dunlop AA, Cree IA, Hague S, Luthert PJ, Lightman S. Multifocal choroiditis: clinicopathologic correlation. Arch Ophthalmol 1998; 116: 801-803.

20 Liversidge J, Forrester JV. Experimental autoimmune uveitis (EAU): immuno-phenotypic analysis of inflammatory cells in chorioretinal lesions. Curr Eye Res 1988; 7: 1231-1241.

21 Stott DI, Hiepe F, Hummel M, Steinhauser G, Berek C. Antigen-driven clonal proliferation of $\mathrm{B}$ cells within the target tissue of an autoimmune disease. The salivary glands of patients with Sjögren's syndrome. J Clin Invest 1998; 102: 938-946.

22 Armengol MP, Juan M, Lucas-Martin A, FernândezFigueras MT, Jaraquemada D, Gallart T et al. Thyroid autoimmune disease. Demonstration of thyroid antigenspecific B cells and recombination-activating gene expression in chemokine-containing active intrathyroidal germinal centers. Am J Pathol 2001; 159: 861-872.

23 Takemura S, Klimiuk PA, Braun A, Goronzy JJ, Weyand $\mathrm{CM}$. T cell activation in rheumatoid synovium is B cell dependent. J Immunol 2001; 167: 4710-4718.

24 Panayi GS. B cells: a fundamental role in the pathogenesis of rheumatoid arthritis? Rheumatology (Oxford) 2005; 44(Suppl 2): ii3-ii7.

25 Kerr MA. The structure and function of human IgA. Biochem J 1990; 271: 285-296.

26 Kaplan S, Hyman K, Brooks R, Wakai M, Hashimoto S, Furie $\mathrm{R}$ et al. Monoclonal IgM, IgG, and IgA human rheumatoid factors produced by snynovial tissue-derived, EBV-transformed B cell lines. Clin Immunol Immunopathol 1993; 66: 18-25. 
27 Pillemer SR, Reynolds WJ, Yoon SJ, Perera M, Newkirk M, Klein M. IgA related disorders in rheumatoid arthritis. J Rheumatol 1987; 14: 880-886.

28 Otten HG, Daha MR, van Laar JM, de Rooy HH, Breedveld FC. Subclass distribution and size of human IgA rheumatoid factor at mucosal and nonmucosal sites. Arthritis Rheum 1991; 34: 831-839.

29 Jorgensen C, Legouffe MC, Bologna C, Brochier J, Sany J. IgA isotype rheumatoid factor in rheumatoid arthritis: clinical implications. Clin Exp Rheumatol 1996; 14: 301-304.

30 Bharadwaj A, Aggarwal A, Misra R. Clinical relevance of IgA rheumatoid factor (RF) in children with juvenile rheumatoid arthritis. Rheumatol Int 1999; 19: 47-49.

31 Matin K, Salam A, Akhter J, Hanada N, Senpuku H. Role of stromal-cell derived factor-1 in the development of autoimmune disease in non-obese diabetic mice. Immunology 2002; 107: 222-231.

32 Balabanian K, Couderc J, Bouchet-Delbos L, Amara A, Berrebi D, Foussat A et al. Role of the chemokine stromal cell-derived factor-1 in autoantibody production and nephritis in murine lupus. J Immunol 2003; 170: 3392-3400.

33 Blades MC, Manzo A, Ingegnoli F, Taylor PR, Panayi GS, Irjala $\mathrm{H}$ et al. Stromal cell-drived factor 1 (CXCL12) induces human cell migration into human lymph nodes transplanted into SCLD mice. J Immunol 2002; 168: 4308-4317.

34 Bradfield PF, Amft N, Vernon-Wilson E, Exley AE, Parsonage G, Rainger GE et al. Rheumatoid fibroblast-like synoviocytes overexpress the chemokine stromal cellderived factor 1 (CXCL12), which supports distinct patterns and rates of $\mathrm{CD} 4^{+}$and $\mathrm{CD} 8^{+} \mathrm{T}$ cell migration within synovial tissue. Arthritis Rheum 2003; 48: 2472-2482.

35 Nanki T, Hayashida K, El-Gabalawy HS, Suson S, Shi K, Girschick HJ et al. Stromal cell-derived factor-1-CXC chemokine receptor 4 interactions play a central role in $\mathrm{CD}^{+} \mathrm{T}$ cell accumulation in rheumatoid arthritis synovium. J Immunol 2000; 165: 6590-6598.

36 Blades MC, Ingegnoli F, Wheller SK, Manzo A, Wahid S, Panayi GS et al. Stromal cell-derived factor 1 (CXCL12) induces monocyte migration into human synovium transplanted onto SCID mice. Arthritis Rheum 2002; 46: 824-836.

37 Fang I-M, Yang C-H, Lin C-P, Yang C-M, Chen M-S. Expression of chemokine and receptors in Lewis rats with experimental autoimmune anterior uveitis. Exp Eye Res 2004; 78: 1043-1055.

38 Kunkel SL, Chensue SW, Strieter RM, Lynch JP, Remick DG Cellular and molecular aspects of granulomatous inflammation. Am J Respir Cell Mol Biol 1989; 1: 439-447.

39 Kreipe H, Radzun HJ, Rudolph P, Barth J, Hansmann ML, Heidorn $\mathrm{K}$ et al. Multinucleated giant cells generated in vitro. Terminally differentiated macrophages with downregulated C-Fms expression. Am J Pathol 1988; 130: 232-243.

40 Jiang Y, Beller DI, Frendl G, Graves DT. Monocyte chemoattractant protein-1 regulates adhesion molecule expression and cytokine production in human monocytes. J Immunol 1992; 148: 2423-2428.

41 Flory CM, Jones ML, Warren JS. Pulmonary granuloma formation in the rat is partially dependent on monocyte chemoattractant protein 1. Lab Invest 1993; 69: 396-404.

42 He W, Casadevall A, Lee SC, Goldman DL. Phagocytic activity and monocyte chemotactic protein expression by pulmonary macrophages in persistent pulmonary Cryptococcosis. Infect Immun 2003; 71: 930-936.
43 Kim J, Chae C. Expression of monocyte chemoattractant protein-1 but not interleukin-8 in granulomatous lesions in lymph nodes from pigs with naturally occurring postweaning multisystemic wasting syndrome. Vet Pathol 2003; 40: 181-186.

44 Iyonaga K, Suga M, Ichiyasu H, Yamamoto T, Hiraga Y, Ando M. Measurement of serum monocyte chemoattractant protein-1 and its clinical application for estimating the activity of granuloma formation in sarcoidosis. Sarcoidosis Vasc Diffuse Lung Dis 1998; 15: 165-172.

45 Elner VM, Burnstine MA, Strieter RM, Kunkel SL, Elner SG. Cell-associated human retinal pigment epithelium interleukin-8 and monocyte chemotactic protein-1: immunochemical and in-situ hybridization analyses. Exp Eye Res 1997; 65: 781-789.

46 Holtkamp GM, Devos AF, Peek R, Kijlstra A. Analysis of the secretion pattern of monocyte chemotactic protein-1 (MCP-1) and transforming growth factor-beta2 (TGF- $\beta 2$ ) by human retinal pigment epithelial cells. Clin Exp Immunol 1999; 118: 35-40.

47 Crane IJ, Wallace CA, McKillop-Smith S, Forrester JV. Control of chemokine production at the blood-retina barrier. Immunology 2000; 101: 426-433.

48 Keino H, Takeuchi M, Kezuka T, Yamakawa N, Tsukahara $\mathrm{R}$, Usui $\mathrm{M}$. Chemokine and chemokine receptor expression during experimental autoimmune uveoretinitis in mice. Graefe's Arch Clin Exp Ophthalmol 2003; 241: 111-115.

49 Adamus G, Manczak M, Machnicki M. Expression of CC chemokines and their receptors in the eye in autoimmune anterior uveitis associated with EAE. Invest Ophthalmol Vis Sci 2001; 42: 2894-2903.

50 Crane IJ, McKillop-Smith S, Wallace CA, Lamont GR, Forrester JV. Expression of the chemokines MIP-1 $\alpha$, MC P-1, and RANTES in experimental autoimmune uveitis. Invest Ophthalmol Vis Sci 2001; 42: 1547-1552.

51 Verma MJ, Lloyd A, Rager H, Strieter R, Kunkel S, Taub D et al. Chemokines in acute anterior uveitis. Curr Eye Res 1997; 16: 1202-1208.

52 El-Shabrawi Y, Christen WG, Foster CT. Correlation of metalloproteinase-2 and -9 with proinflammatory cytokines interleukin- $1 \beta$, interleukin-12 and the interleukin- 1 receptor antagonist in patients with chronic uveitis. Curr Eye Res 2000; 20: 211-214.

53 Abu El-Asrar AM, Struyf S, Descamps FJ, Al-Obeidan SA, Proost P, Van Damme J et al. Chemokines and gelatinases in the aqueous humor of patients with active uveitis. Am J Ophthalmol 2004; 138: 401-411.

54 Hibbs MS. Expression of $92 \mathrm{kDa}$ phagocyte gelatinase by inflammatory and connective tissue cells. Matrix Suppl 1992; 1: 51-57.

55 Price NM, Gilman RH, Uddin J, Recavarren S, Friedland JS. Unopposed matrix metalloproteinase-9 expression in human tuberculous granuloma and the role of TNF- $\alpha$-dependent monocyte networks. J Immunol 2003; 171: 5579-5586.

56 Grillet B, Dequeker J, Paemen L, Van Damme B, Opdenakker G. Gelatinase B in chronic synovitis: immumolocalization with a monoclonal antibody. Br J Rheumatol 1997; 36: 744-747.

57 Gonzâlez AA, Segura AM, Horiba K, Qian S, Yu Z-X, Stetler-Stevenson $\mathrm{W}$ et al. Matrix metalloproteinases and their tissue inhibitors in the lesions of cardiac and pulmonary sarcoidosis: an immunohistochemical study. Hum Pathol 2002; 33: 1158-1164.

58 Opdenakker G, Van Damme J. Cytokine-regulated proteases in autoimmune diseases. Immunol Today 1994; 15: 103-107. 
59 Van den Steen PE, Proost P, Grillet B, Brand DD, Kang AH, Van Damme J et al. Cleavage of denatured natural collagen II by neutrophil gelatinase B reveals enzyme specificity, post-translational modifications in the substrate, and the formation of remnant epitopes in rheumatoid arthritis. FASEB J 2002; 16: 379-389.

60 Descamps FJ, Van den Steen PE, Martens E, Ballaux F, Geboes K, Opdenakker G. Gelatinase B is diabetogenic in acute and chronic pancreatitis by cleaving insulin. FASEB $J$ 2003; 17: 887-889.
61 Murphy G, Cookett MI, Ward RV, Docherty AJP. Matrix metalloproteinase degradation of elastin, type IV collagen and proteoglycan. A quantitative comparison of the activities of 92 and $72 \mathrm{kDa}$ gelatinases, stromelysins -1 and -2 and punctuated metalloproteinase (PUMP). Biochem J 1991; 277: 277-279.

62 El-Shabrawi S, Walch A, Hermann J, Egger G, Foster CS. Inhibition of MMP-dependent chemotaxis and amelioration of experimental autoimmune uveitis with a selective metalloproteinase-2 and -9 inhibitor. J Neuroimmunol 2004; 155: 13-20. 